\title{
Germeçtepe Baraj Gölünün (Kastamonu-Daday) Bazı Fiziko-Kimyasal Su Kalite Parametrelerinin İncelenmesi
}

\begin{tabular}{l|c}
\hline Araştırma /Research & \\
Gelis Tarihi /Received & Enas A. Hamad ATEA*, Ali Eslem KADAK, \\
28.05.2017 & Adem Yavuz SÖNMEZ \\
Kabul Tarih /Accepted & \\
19.06.2017 & Kastamonu Üniversitesi, Su Ürünleri Fakültesi, Kastamonu-Türkiye \\
DOI & \\
10.28955/alinterizbd.316483 & *e-posta: enassatia.ea@gmail.com \\
ISSN 2564-7814 & \\
e-ISSN 2587-2249 & \\
\hline
\end{tabular}

Öz: Bu çalışmada Kastamonu ili Daday ilçesi sınırları içerisinde bulunan Germeçtepe baraj gölünün su kalitesinin değerlendirilmesi amacı ile göl üzerinde belirlenen üç istasyondan bir yıl boyunca alınan su numuneleri sıcaklık, pH, turbidite, kondüktivite, çözünmüş oksijen, nitrat, nitrit, fosfat, amonyum, KOİ ve BOİ olmak üzere 11 fiziko-kimyasal parametre bakımından incelenmiştir. Su numunelerinden sıcaklık, $\mathrm{pH}$, kondüktivite ve çözünmüş oksijen parametreleri örnekleme esnasında multimetre cihazı ile diğer parametreler ise sprektrofotometrik metotla laboratuvarda analiz edilmiştir. Göl suyunda tespit edilen fizikokimyasal parametrelerden sicaklığın $1,07-24,5^{\circ} \mathrm{C}$ arasında, $\mathrm{pH}$ 'nın 7,32-9,98, turbiditenin 0,748,17 NTU, çözünmüş oksijenin 7,23-11,35 mg 1-1, kondüktivitenin 332-459 $\mu \mathrm{S} \mathrm{cm}-1$, nitritin 0,0-0,008 mg 1-1, nitratın 0,0-0,87 mg 1-1, fosfatın 0,04-3,53 mg 1-1, amonyumun 0,0-0,53 mg 1-1, KOİ'nin 8,41-23,13 mg 1-1 ve BOİ'nin 0,0-2,0 mg 1-1 arasında değiştiği tespit edilmiştir. Sonuç olarak Germeçtepe baraj gölü su kalitesi yüzey suları yönetmeliğine göre sıcaklık, pH, çözünmüş oksijen, kondüktüvite, nitrat, amonyum, KOİ ve BOİ parametreleri bakımından I. kalite, nitrit bakımından II. Kalite ve fosfat bakımından ise IV. Kalite su sınıfında olduğu tespit edilmiş ve göl suyunun önemli bir kirlilik baskısında olmadığ belirlenmiştir.

Anahtar Kelimeler: Su kalitesi, Germeçtepe Baraj Gölü, fizikokimyasal analizler.

\section{Investigation of Physicochemical Water Quality Parameters of Germeçtepe Dam Lake (Kastamonu-Daday)}

\begin{abstract}
The aim of this study is to evaluate the water quality of Germeçtepe dam lake located in the Daday district of Kastamonu province and to determine the temperature, $\mathrm{pH}$, turbidity, conductivity, dissolved oxygen, nitrate, nitrite, phosphate, ammonia, COD and BOD in terms of 11 physico-chemical parameters. The temperature, $\mathrm{pH}$, conductivity and dissolved oxygen parameters of the water samples were analyzed study land using multimeter and other parameters were determined using sproctrophotometric method in the laboratory. The physicochemical parameters determined in the lake water were between $1.07-24.5^{\circ} \mathrm{C}, \mathrm{pH} 7.32-9.98$, turbidity 0.74-8.17 NTU, dissolved oxygen $7.23-11.35 \mathrm{mg}-1$, conductivity $332-459 \mu \mathrm{S} \mathrm{cm}-1$, nitrite $0.0-0.008 \mathrm{mg}-1$, nitrate $0.0-0.87 \mathrm{mg}-1$, phosphate $0.04-3.53 \mathrm{mg}-1$, ammonium $0.0-0.53$ $\mathrm{mg}-1$, COD 8.41-23.13 mg-1 and BOD Has been found to vary between 0.0 and $2.0 \mathrm{mg}-1$. All of the a data set (12 months) about several physico-chemical parameters such as temperature, $\mathrm{pH}$, conductivity, dissolved oxygen, nitrate, nitrite, phosphate, Ammonia, COD and BOD was collected from 3 monitoring stations in Germeçtepe Dam Lake were evaluated with statistical analysis. In the results of the analysis, Germeçtepe dam reservoir water quality was determined as the first quality in terms of temperature, $\mathrm{pH}$, dissolved oxygen, conduction, nitrate, ammonium, COD and BOD parameters in terms of nitrite. In terms of quality and phosphate, IV. It has been determined that quality is in the water class and it is determined that the lake water is not in an important pollution pressure.
\end{abstract}

Keywords: Water quality, Germectepe Dam Lake, physicochemmical analysis

\section{GİRIS}

Canlıların etkileşim içerisinde bulundukları çevre unsurunun birçok bileşeni olmasına karşın hiç şüphesiz bunların en başında su gelmektedir. Su ikame edilemez olmasından dolayı diğer çevreyi 
oluşturan unsurlardan ayrılırken, yaşamsal döngünün devamı kadar sürdürülebilir kalkınmanın da en temel ayaklarından birisini oluşturmaktadır.

Yeryüzünün önemli bir bölümü sularla kaplı olmasına karşın kullanılabilir su miktarı oldukça azdır. Ancak su döngüsü sayesinde mevcut kullanılabilir su, tüm canlıların yaşamlarını sürdürebilmelerine imkân vermektedir. Ekonomik büyüme ile ekosistemin korunması ve çevresel sürdürülebilirliğin sağlanması insan ile doğayı karşı karşıya getirmiştir. Bunun sonucu olarak doğal sebeplerin yanı sıra insan faaliyetlerinin yol açtığı zararlar, sınırlı olan su kaynakları üzerinde baskı oluşmasına ve küresel su sorunlarının yaşanmasına sebep olmuştur (Şahin, 2016).

Kullanım alanlarına göre kalite parametrelerinin düzeyleri farklılık gösterirken kirliliğe kaynaklık eden farklı unsurlar söz konusudur. Kaynaklarına göre kirletici unsurlar fiziksel, kimyasal veya biyolojik karakter gösterebilmektedir. $\mathrm{Bu}$ bağlamda su kalitesinin ve kirlilik düzeyinin belirlenmesinde özellikle yüzey sularında sıcaklık, pH, oksijen düzeyi, elektirik iletkenliği, bulanıklık, nitrat, nitrit, fosfat, biyolojik oksijen ihtiyacı ve kimyasal oksijen ihtiyacı gibi birçok parametre temel kriter alınabilmektedir. Bu kriterlerin her biri su kaynağının barındırdığı biyolojik çeşitliliğin yaşamsal döngüsü açısından önem arz etmesinin yanı sıra içme ve sulama suyu olarak kullanımları dolaysıyla insan sağlığını da direk ilgilendirmektedir.

Kirlilik unsurlarının sürekliliği ve nitelik değişiklikleri ile dinamik bir yapı göstermesi bu yönlü çalışmaların ekosistemler açısından periyodik aralıklarla tekrarlanmasını gerektirmektedir. Su kaynaklarının su kalite parametrelerinin belirlenmesi karar mekanizmalarına doğru yön göstermesi ve etkin su yönetimi açısından önemlidir.

Nitekim bu çalışmada Kastamonu İli Daday İlçesi sınırları içerisinden bulunan, üzerinde su ürünleri yetiştiriciliği yapılan ve ayrıca önemli bir biyoçeşitliliğe sahip olan Germeçtepe Baraj gölünün bazı fiziko-kimyasal su kalite parametreleri bir yıl boyunca izlenmiş ve gölün kirlilik düzeyi ortay koyulmaya çalışılmıştır.

\section{MATERYAL VE YÖNTEM}

Araştırma alanını Kastamonu ili Daday ilçesi sınırları içerisinde bulunan Germeçtepe Baraj Gölü oluşturmaktadır. Araştırma istasyonu olarak baraj gölü üzerinde üç istasyon belirlenmiş ve örneklemeler bu noktadan yapılmıştır. İstasyonların belirlenmesinde baraj gölünün fiziki yapısı, beslendiği bölge, su ürünleri işletmelerinin konuşlandığı yerler dikkate alınmıştır.

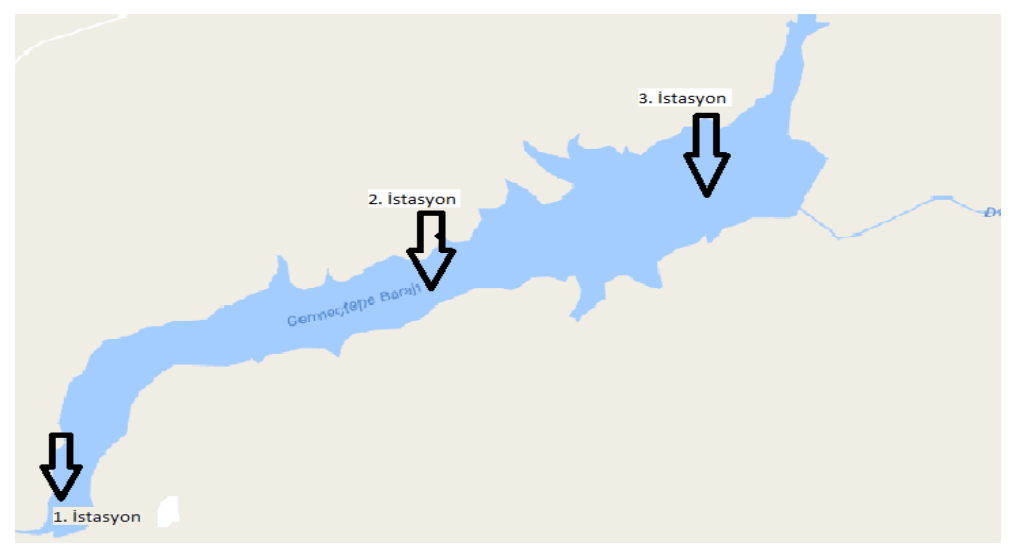

Şekil 1. Çalışma sahası ve istasyonlar

Göl su içeriğinin fiziko-kimyasal özelliklerini araştırmak için, su numunelerinin toplanması 2016 yılın Ocak ayından Aralık ayına kadar 12 aylık sürede devam etmiş̧ir. Su numuneleri, polietilen, koyu renkli şişelerin içinde toplanmıştır. İlk olarak, önceden yıkanan şişeler saf su ile durulanmıştır. Kapalı şişe, $1 \mathrm{~m}$ derinliğinde göle daldırılmıştır ve daha sonra içerisinde açılmıştır ve yüzeyde dışarı çıarmak için tekrar kapatılmıştır.

Sıcaklık, Çözünmüş Oksijen, pH, elektrik iletkenlik parametreleri su numunesi alınmasıyla eş zamanlı Hach Lange marka, HQ40d model dijital multimetre cihazı ile kaydedilmiştir. Bulanıklık parametresi de yine su numunesi alımı esnasında anlık olarak WTW marka Turb $^{\circledR} 430$ model bulanıklık ölçer ile kayıt altına alınmıştır. Nitrat, nitrit, fosfat, amonyum, BOİ ve KOİ parametreleri spektrofotometrik 
metotla belirlenmiş olup aynı gün laboratuvara getirilen örnekler Hach Lange UV VIS Allınteri Spektorofotometre ve Hach Lange lt200 termoreaktör cihazları kullanılarak analiz edilmiştir.

Su Kalite sınıflarının oluşturulmasında ve ölçülen su parametrelinin yorumlanmasında 2012 yılında revize edilerek resmi gazete yayınlanan Yüzey Suları yönetmeliğinde belirtilen " Kıta içi Yüzeysel Su Kaynaklarının Sınıflarına Göre Kalite Kriterleri'” esas alınıştır. Ayrıca çalışmada ölçümü yapılan parametrelerle ilgili uluslararası standartlarda ulaşılabilen parametrelerde dikkate alınmıştır.

Çizelge 1. Yüzey Suları Yönetmeliğine Göre Kıta içi Yüzeysel Su Kaynaklarının Kalite Sınıfları (YSY, 2012)

\begin{tabular}{|c|c|c|c|c|}
\hline \multirow{2}{*}{ Su Kalite Parametreleri } & \multicolumn{4}{|c|}{ Su Kalite Sınıfları } \\
\hline & I & II & III & IV \\
\hline Sicaklık ( $\left.{ }^{0} \mathrm{C}\right)$ & $\leq 25$ & $\leq 25$ & $\leq 30$ & $>30$ \\
\hline pH & $6,5-8,5$ & $6,5-8,5$ & $6,0-9,0$ & $6,0-9,0$ dişında \\
\hline İletkenlik $(\boldsymbol{\mu S} / \mathbf{c m})$ & $<400$ & $400-1000$ & $1001-3000$ & $>3000$ \\
\hline Çözünmüş oksijen $\left(\mathrm{mg} \mathrm{O}_{2} / \mathrm{L}\right)$ & $>8$ & $6-8$ & $3-6$ & $<3$ \\
\hline $\begin{array}{l}\text { Kimyasal oksijen ihtiyacı } \\
\text { (KOİ) }(\mathrm{mg} / \mathrm{L})\end{array}$ & $<25$ & $25-50$ & $50-70$ & $>70$ \\
\hline $\begin{array}{l}\text { Biyolojik oksijen ihtiyacı } \\
\left(\mathrm{BOI}_{5}\right)(\mathrm{mg} / \mathrm{L})\end{array}$ & $<4$ & $4-8$ & $8-20$ & $>20$ \\
\hline $\begin{array}{l}\text { Amonyum azotu } \\
\left(\mathrm{mg} \mathrm{NH}_{4}^{+}-\mathrm{N} / \mathrm{L}\right)\end{array}$ & $<0,2^{\mathrm{b}}$ & $0,2-1^{\mathrm{b}}$ & $1-2^{b}$ & $>2$ \\
\hline Nitrit azotu $\left(\mathrm{mg} \mathrm{NO}_{2}^{-}-\mathrm{N} / \mathrm{L}\right)$ & $<0,002$ & $0,002-0,01$ & $0,01-0,05$ & $>0,05$ \\
\hline Nitrat azotu $\left(\mathrm{mg} \mathrm{NO}_{3}^{-}-\mathrm{N} / \mathrm{L}\right)$ & $<5$ & $5-10$ & $10-20$ & $>20$ \\
\hline Toplam fosfor (mg P/L) & $<0,03$ & $0,03-0,16$ & $0,16-0,65$ & $>0,65$ \\
\hline
\end{tabular}

Çizelge 2. Uluslararası standartlara göre bazı su kalite parametreleri üst limitleri

\begin{tabular}{llll}
\hline & $\begin{array}{l}\text { Dünya Sağlık } \\
\text { Örgütü } \\
\text { (WHO) 2008 }\end{array}$ & $\begin{array}{l}\text { ABD Çevre } \\
\text { Koruma Ajansı } \\
(\text { EPA) 2009 }\end{array}$ & $\begin{array}{l}\text { Avrupa } \\
\text { Birliği } \\
\text { (EC) 1998 }\end{array}$ \\
\hline Bulanıklık (NTU) & 5 & 1 & 1 \\
\hline Nitrat $\left(\mathbf{N O}_{3}\right)$ & 50 & 10 & 50 \\
\hline Nitrit $\left(\mathbf{N O}_{2}\right.$ ) & 0,50 & 0,50 & 0,50 \\
\hline Iletkenlik 20' (Us/cm) & 2500 & - & 2500 \\
\hline Sicaklık $\left({ }^{\circ} \mathbf{C}\right)$ & - & - & - \\
\hline PH & $6,5-8,0$ & $6,5-8,5$ & $6,5-9,5$ \\
\hline Amonyum & 1,5 & - & 0,5 \\
\hline
\end{tabular}

Verilerin istatistiki olarak değerlendirilmesinde Varyans analizi uygulanmış ve farklılığın ortaya koyulabilmesi için Duncan çoklu karşılaştırma testi uygulanmıştır. İstatistiki analizler SPSS paket programda yapilmıştır.

\section{ARASSTIRMA BULGULARI VE TARTISMA}

Su sıcaklığı, su ekosistemlerin en önemli fiziksel özelliklerinden biridir. Suyun sıcaklığı kara parçalarında olduğu gibi çok büyük ölçülerde güneşe bağlıdır. Dolayısıyla mevsimlere, günün çeşitli saatlerine, havanın sıcaklığına, yağış durumuna, coğrafik konuma ve suyun derinliğine göre değişmektedir. Suyun sıcaklığı su biyolojisine direk ve indirek olarak etki etmektedir. Öte yandan su sıcaklığ diğer bir kısım su kalite parametrelerine de dolaylı yoldan etki etmesinden dolayı su kalitesi parametreleri bakımından belirleyici bir unsurdur (Sönmez, 2008).

Baraj gölünde üç istasyondan ölçülen 12 aylık sıcaklık değiş̧imleri Şekil 1'de verilmiştir. 


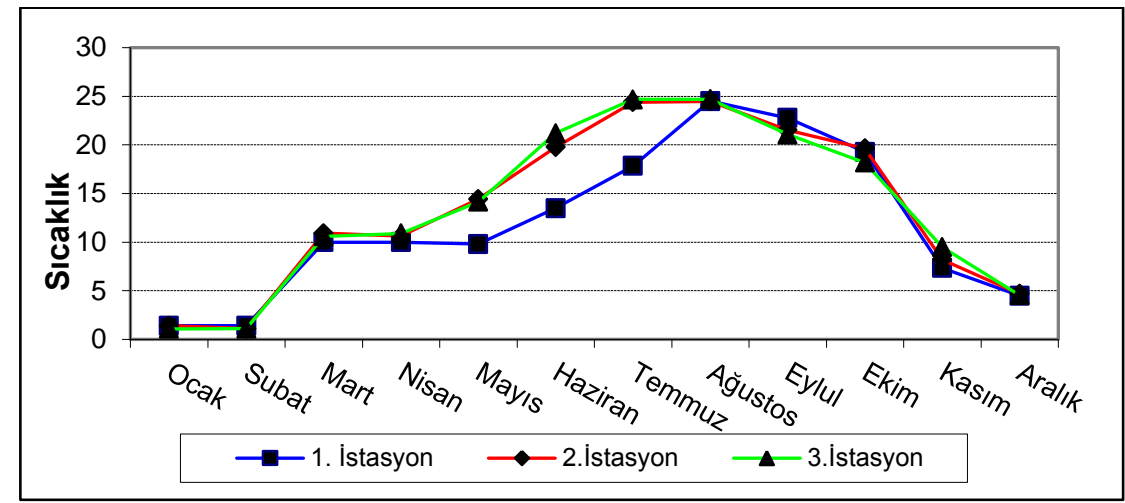

Şekil 1. Sıcaklığın istasyonlara göre aylık değişimi $\left({ }^{\circ} \mathrm{C}\right)$

Çalışmadan elde edilen sıcaklık verilerine göre en düşük sıcaklık Ocak ayında 3. İstasyonda $1,07^{\circ} \mathrm{C}$ ile ölçülürken, en yüksek sıcaklık $24,5^{\circ} \mathrm{C}$ ile Ağustos ayında 1. İstasyonda ölçülmüsstür.

Ünlü vd., (2008) Hazar gölünde yaptıkları çalışmada Sıcaklığın aylara ve derinliklere göre büyük değişimler gösterdiğini vurgularken istasyonlarda su sıcaklığının $5-26,5^{\circ} \mathrm{C}$ arasında değiştiğini rapor etmiştir. Hatay'ın Reyhanlı ilçesindeki Yenişehir göletinde yapılan bir başka çalışmada $\mathrm{Su}$ sıcaklığının mevsimsel olarak değişim gösterdiği, en düşük sıcaklığının Ocak ayında $14,6^{\circ} \mathrm{C}$, en yüksek sıcaklığın ise Ağustos ayında $29,7^{\circ} \mathrm{C}$ olduğu bildirilmiştir (Tepe, 2009). Ordu ilinde bulunan Gaga gölünde 2005-2006 yılları arasında yürütülen su kalitesi belirlenmesi çalışmasında sıcaklığın $9,40-22,8^{\circ} \mathrm{C}$ arasında değiştiği ve su kalite sınıfları bakımından I. Kalite olduğu bildirilmiştir (Taş, 2011). Ordu ilinde başka bir gölet olan Gökgöl'de ise yapılan çalışmada ortalama su sicaklığının yüzeyde $23,2^{\circ} \mathrm{C}, 5 \mathrm{~m}$ derinlikte de $20,75^{\circ} \mathrm{C}$ olduğu ve su kalitesinin I. Sınıf olduğu belirlenmiştir ( Taş ve Çetin, 2011). Eğrigöl'ün su kalite parametrelerinin belirlenmesine yönelik yapılan bir başka çalışmada ise su sıcaklığının $8,3-21,1^{\circ} \mathrm{C}$ arasında değiştiği rapor edilmiştir.

Germeçtepe baraj gölünde yaptığımız çalışmada sıcaklığa ilişkin veriler litaratürle uyum gösterirken genel periyotta oldukça değişkenlik gösterdiği bunun sebebi olarak ise göl suyunun belirli mevsimlerde sürekli azalıp artması, derinliğin fazla olmayışı, yağış miktarı ve bölgenin iklim koşulları olduğu tahmin edilmektedir. Genel sicaklık ortalamas $12,72^{\circ} \mathrm{C}$ olarak tespit edilmiş olup baraj gölünün su kalitesi Yüzey Suları Yönetmeliğine göre I. Kalite olarak değerlendirilmiştir.

pH suyun asitliği ve alkaliliği ile ilgilidir. Genellikle hidrojen iyonları konsantrasyonunu ifade eder. pH'ın su canlıları üzerine çok büyük etkileri vardır. Genellikle 6-8,5 pH aralığı birçok su canlısı için ideal yaşama ortamını teşkil etmektedir. Özellikle göllerde $\mathrm{pH}$ derecesi amonyum- amonyum dioksit oranını etkilemektedir. Bu nedenle $\mathrm{pH}$ su kalitesi açısından oldukça önemli bir parametredir (Sönmez, 2008).

Germeçtepe baraj gölünden 12 ay boyunca üç istasyondan elde edilen pH değerleri Şekil 2'de verilmiştir.

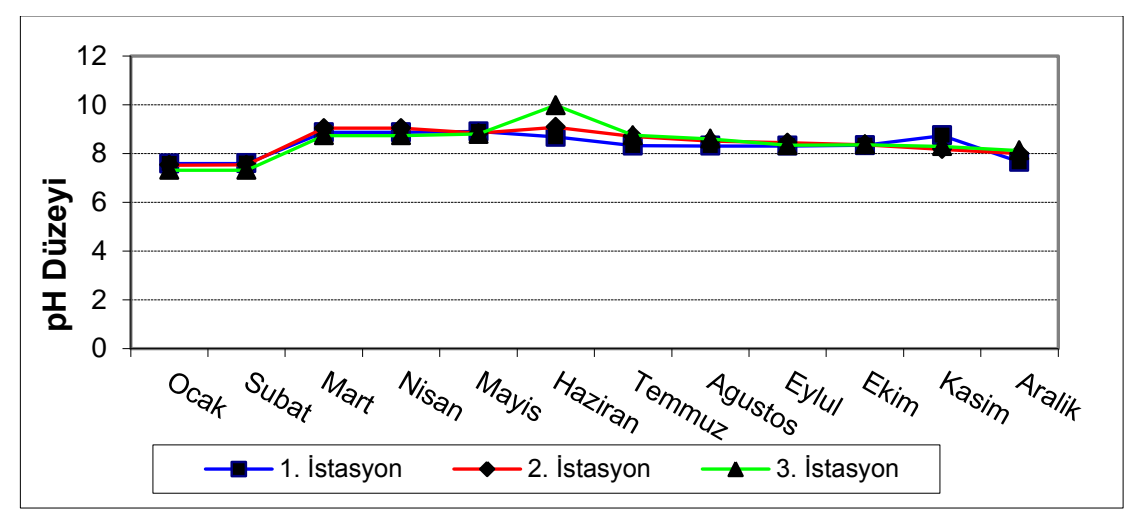

Şekil 2. pH'nın istasyonlara göre aylık değiş̧imi 
Çalışmada pH düzeyi 7,32 ile 9,98 arasında değişiklik gösterirken ilkbahar ve yaz aylarında bazı istasyonlarda artış olduğu gözlenmişse de genel anlamda değerler benzer seyretmiştir. Verilerin istatistiki analizlerinde $\mathrm{pH}$ değişimlerinin istasyonlar arasında farklılık göstermediği fakat mevsimsel olarak farklılığın istatistiki olarak anlamlı olduğu $(\mathrm{p}<0.01)$ tespit edilmiştir. Ayrıca mevsimler $\mathrm{x}$ istasyonlar interaksiyonunun istatistiki bakımdan önemli olmadığı belirlenmiştir.

Obalı (1978), Mogan Gölü'nde yaptığı bir çalışmada, göl suyunun pH değerini 8,5- 9,2, Altuner'in (1982), Tortum Gölü'nde yaptığı araştırmaya göre pH 8-8,5, Anonim (1983), Bafra Balık Gölü'nde yapılan bir yıllık limnolojik çalışmada ise göl suyunun $\mathrm{pH}$ değerinin 8,1-8,6 arasında olduğu rapor edilmiştir.

Taş ve Çetin (2011), Gökgöl'de yaptığı çalışmada ortalama pH düzeyini yüzey sularında 6,31, 5m derinlikte ise 5,99 olarak tespit etmiştir. Şengörür ve Demirel (2002), Sakarya Akgöl'de yaptığ çalışmada $\mathrm{pH}$ değerlerinin mevsime ve derinliğe bağlı olarak değişim gösterdiğini belirtirken, yüzeyde en yüksek pH değeri 9,87 ile Temmuz ayında, en düşük 7,94 ile Aralık ayında ölçüldüğünü bildirmiştir. İleri, Karaer, Katip ve Onur (2014), Ulubat gölünde yaptıkları çalışmada pH değerlerinin mevsimsel ortalamalarının birbirine yakın olmakla birlikte en yüksek değerin yaz mevsiminde, Temmuz ayında 8,64 olarak ölçüldüğünü bildirmiştir. Temmuz ayındaki bu yüksek pH değerinin nedeni olarak ta yaz aylarında artan fotosentez sırasında planktonların çözünmüş inorganik karbonu asimile etmeleri sırasında asidik özelliğin azalması ve alkalinitenin artmasının olabileceğini rapor etmişlerdir.

Çalışmamızda elde edilen pH değerleri genel anlamda literatürle uyum göstermektedir. pH düzeyinde yaz aylarında artış meydana geldiği görülmektedir. $\mathrm{pH}$ çok büyük ölçülerde sudaki karbondioksit miktarına bağlı ve onla ters orantılıdır. Karbondioksit yükseldikçe düşmekte, düştükçe yükselmektedir. Dolayısıyla yaz mevsimlerinde karbondioksit sıcak sularda daha az çözüleceği için pH yüksek olmakta, aksine kış aylarında ise düşük olmaktadır (Sönmez, 2008). Öte yandan ölçülen pH değeri ortalaması 8,34 olarak belirlenmiş ve Yüzey Suları Yönetmeliğine göre I. Kalite olarak değerlendirilirken Dünya sağlık Örgütü (2008), ABD Çevre Koruma Ajansı (2009) ve Avrupa Birliği (1998)' de belirtilen limitlere göre kabul edilebilir sınırlar içerisinde olduğu tespit edilmiştir. Ayrıca genel ortalama ve mevsimsel izlenimler bakımından göl suyunun bazik karakterde olduğu tespit edilirken Karadeniz bölgesindeki göllerin genel itibarla bazik karakterde oldukları bildirilmektedir (Verep ve ark., 2002; Taş, 2006; Özbek ve Sarı, 2007; Taş ve ark., 2010).

Turbidite suyun bulanıklık düzeyini ifade etmektedir. Bulanıklık su kalitesi açısından oldukça önemli bir parametredir. Çünkü bulanıklık sudaki yaşamsal döngüye direk etki eden 1şık geçirgenliğini etkilemekte ve fotosentez olayına mani olarak fitoplankton gelişimini olumsuz etkilemektedir. Yine sudaki görüşü kısıtlamakta ve buna bağlı olarak balık ve diğer su canlılarının besin bulmalarını güçleştirmektedir. Genellikle her litresinde $25 \mathrm{mg}$ 'dan daha az kil bulunan sulara berrak, 25-100mg arasında bulunanlara orta bulanık, daha fazla bulunanlara ise bulanık sular adı verilmektedir (Aras, 1997; Sönmez, 2008) Bulanıklık, süspansiyon veya solüsyon halinde bulunan maddelerden dolayı dağılan 1şığın ölçümüdür ve NTU (Nephelometric Turbidity Units) ile ölçülür. Germeçtepe baraj gölünden 12 ay boyunca üç istasyondan elde edilen $\mathrm{pH}$ değerleri Garfik 3'de verilmiştir.

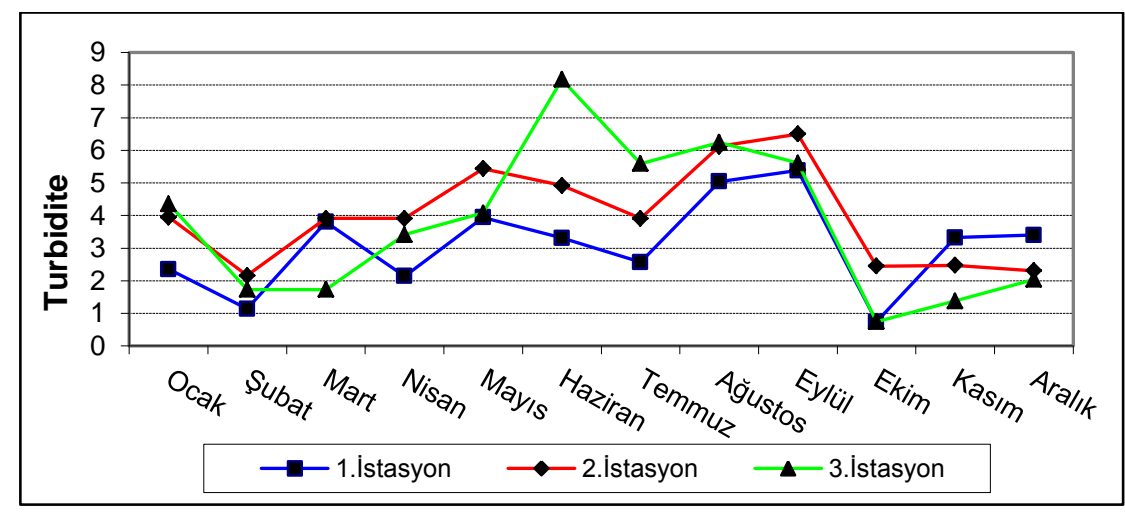

Şekil 3. Turbidite'nin istasyonlara göre aylık değişimi (NTU) 
Çalışmada elde edilen bulanıklık verileri 0,74- 8,17 arasında değişim gösterirken genel ortalama 3,46 olarak tespit edilmiştir. Verilerin istatistiki analizlerinde bulanıklık değişimlerinin istasyonlar arasında farklılık göstermediği fakat mevsimsel olarak farklılığın istatistiki olarak anlamlı olduğu $(\mathrm{p}<0.05)$ tespit edilmiştir. Ayrıca mevsimler $\mathrm{x}$ istasyonlar interaksiyonunun istatistiki bakımdan önemli olmadığı belirlenmiştir.

Alp, Koçer, Şen ve Özbay (2010), Güneydoğu Anadolu bölgesindeki baraj göllerinde yaptıkları araştırmada Bulanıklık değerini Atatürk Barajında, Birecik Barajında, Karkamış Barajında, Hacı Hıdır Barajında 5-20NTU arasında değişiklik gösterdiğini bildirmişlerdir. Ayrıca bulanıklık ve TSS düzeyi ile özellikle sodyum, potasyum ve sülfat, düzeyi arasından yüksek bir ilişki olduğunu ve yağışların artış gösterdiği mevsimlerde artış seyrinde olduğunu bildirmiştir. Bayram ve Kenanoğlu (2016) Borçka barajında yaptıkları çalışmada bulanıklık düzeyini 46NTU olarak bildirmiştir.

Bulanıklık verileri çalışmamızda genel anlamda literatür bilgileri ile uyumlu olmakla birlikte daha düşük seyretmiştir. Özellikle İlkbahar ile başlayıp yazın devam eden nspeten yüksek bulanıklık düzeyleri ilkbaharda yağışlarla birlikte suya taşınımındaki artışı, kar sularının eriyerek baraja karışması ve yaz aylarında ise su miktarındaki azalmaya bağlı olabileceği kanaati ortaya çıkmıştır. Bulanıklık ile ilgili Yüzey Suları Yönetmeliğinde belirtilen bir kategori bulunmasa da Dünya Sağlık Örgütü (2008) sınıflandırmasına göre tahammül limitleri içerisinde, ABD Çevre Koruma Ajansı (2009) ve Avrupa Birliği (1998) sınıflandırmasına göre yüksek bulunmuştur.

Çözünmüş oksijen, su kalitesi değerlendirmesindeki önemli parametrelerden biridir ve suda yaygın olan biyolojik ve fiziksel proseslerini yansıtmaktadır. Çözünmüş oksijen, su yaşamı ve fiziksel çevre özellikleri için önemli bir unsurdur (Egemen, 2011). Çözünmüş oksijen, bütün canlı organizmalar için büyük önem arz etmektedir ve bütün su kütlesinin ekolojisini ortaya çıkarabilecek kadar önemli ölçüde tek parametre olarak değerlendirilmektedir. Ötrofik su kütlelerinin, geniş bir çözünmüş oksijen yelpazesi varken oligotrof su kütlelerinin dar bir çözünmüş oksijen aralığı vardır (Rucinski vd ., 2010). Nihai olarak çözünmüş oksijen düzeyinin belirlenmesi bütün su kaynaklarının kalite değerlendirmelerinde önemli bir unsurdur.

Germeçtepe baraj gölünden elde edilen çözünmüş oksijen verilerimiz 7,23-11,35 mg $\mathrm{l}^{-1}$ arasında değişmektedir. Ortalama oksijen düzeyi $9,07 \mathrm{mg} \mathrm{l}^{-1}$ olarak belirlenmiş ve Şekil 4 'te verilmiştir.

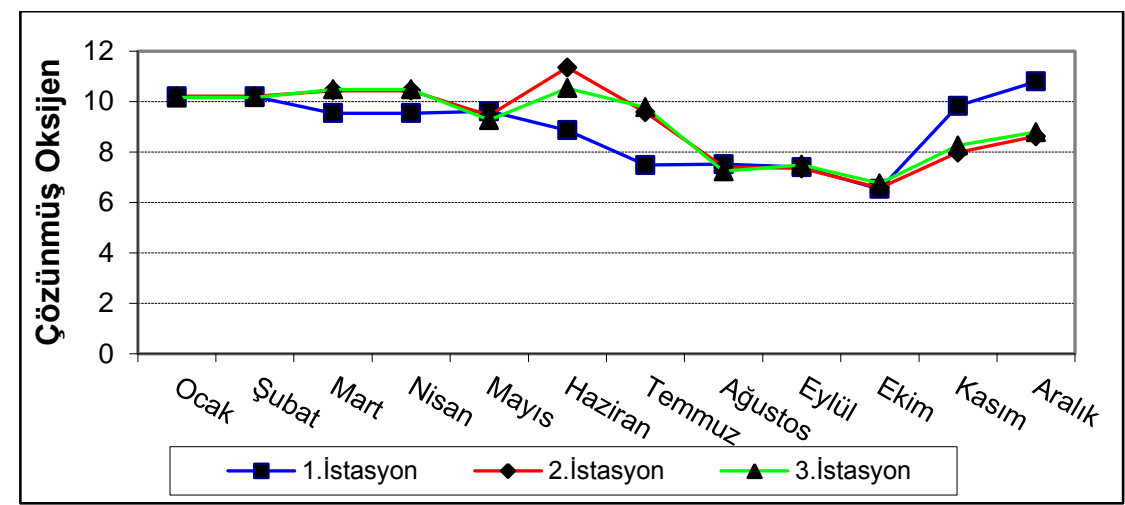

Şekil 4. Çözünmüş Oksijen düzeyinin istasyonlara göre aylık değişimi $\left(\mathrm{mg} \mathrm{l}^{-1}\right)$

Çözünmüş Oksijen verilerinin istatistiki analizlerinde istasyonlar arasında farklılık tespit edilmediği fakat mevsimseler arasında istatistiki olarak anlamlı fark olduğu $(p<0.01)$ belirlenmiştir. Ayrıca mevsimler $\mathrm{x}$ istasyonlar interaksiyonunun istatistiki bakımdan önemli olmadığı belirlenmiştir.

Şengörür ve Demirel (2002), Akgöl'de yaptığı çalışmada çözünmüş oksijen düzeyini yüzeyde en yüksek $10 \mathrm{mg} / \mathrm{l}$ olarak Aralık ayında, en düşük $0,93 \mathrm{mg} / 1$ olarak Temmuz ayında, dipte en yüksek olarak $8 \mathrm{mg} / 1$ olarak Aralık ayında, en düşük olarak $0.17 \mathrm{mg} / \mathrm{l}$ olarak Temmuz ayında rapor etmiştir. Ulubat Gölü'nde yapılan bir diğer çalışmada 3,43-12,09mg/1 arasında değiştiği (İleri vd. 2014), Reyhanlı Gölünde yapılan çalışmada 6,32-12,19 arasında olduğu (Tepe, 2009), Eğrigöl'de yapılan çalışmada yüzey suyunda 5,6-7,9 mg/l arasında değiştiği (Başaran ve Egemen 2006), Gaga Gölü'ndeki çözünmüş oksijen değerinin ortalama 9,92 mg/l olduğu (Taş, 2011), Uzungöl'de 3,72 13,13 mg/l (Verep ve ark., 2002), Batı Karadeniz Bölgesi göllerinde 5,1 - 10,3 mg/1 (Özbek ve Sarı, 2007), Ulugöl'de 8,4-11,3 mg/l ölçüldüğü (Taş ve ark., 2010) bildirilmiştir. 
Çalışma verilerimiz literatür bilgileri ile uyum göstermekle birlikte yapılan çalışmalar paralel olara ilkbahar ve kış aylarında yüksek seyretmiş yaz aylarında ise düşüş gözlenmiştir. Çözünmüş oksijenin suyun sıcaklığı ile direk ilişkili olması yaz aylarındaki düşüşün ve rahatlıkla açıklanabilmesine olanak sağlamaktadır. Ayrıca göl suları 9,07 $\mathrm{mg} \mathrm{l}^{-1}$ genel ortalama ile Yüzey Suları Yönetmeliğinde belirtilen sınıflandırmaya göre I. Kalite'de sınıflandırılmıştır.

Sularda bulunan iyon konsantrasyonunun anlaşılabilmesi adına geliştirilmiş olan bir parametre olup, sulardaki çözünmüş katı maddelerden ileri gelmektedir. Doğal sularda rastlanabilecek başlıca çözünmüş katı maddeler genellikle nitratlar, fosfatlar, karbonatlar, sülfatlar ve klorürlerdir. Ancak bunların yanı sıra sodyum, potasyum, kalsiyum, magnezyum, demir ve mangan gibi bazı metallerinde etki ettiği bilinmektedir. Aslında sulardaki elektiriksel iletkenliği oluşturan başlıca etkenler çözünmüş̧ tuzlardır. Bu nedenle suyun kondüktüvite değeri tahmini bir tuzluluk değeri verebilmektedir. Genel anlamda su ürünleri yetiştiriciliği yapılacak sularda iletkenliğin $12,5-1800 \mu \mathrm{S} \mathrm{cm}^{-1}$ arasında olması tavsiye edildiği bildirilmektedir (Göksu, 2003).

Germeştepe barajından 12 ay boyunca ölçümü yapılan elektriksel iletkenlik değerleri $332-459 \mu \mathrm{S} \mathrm{cm}^{-1}$ arasında değimim gösterdiği belirlenmiştir. Bazı aylarda istasyonlar arasında değişimler görülmüş ve Şekil 5'te verilmiştir.

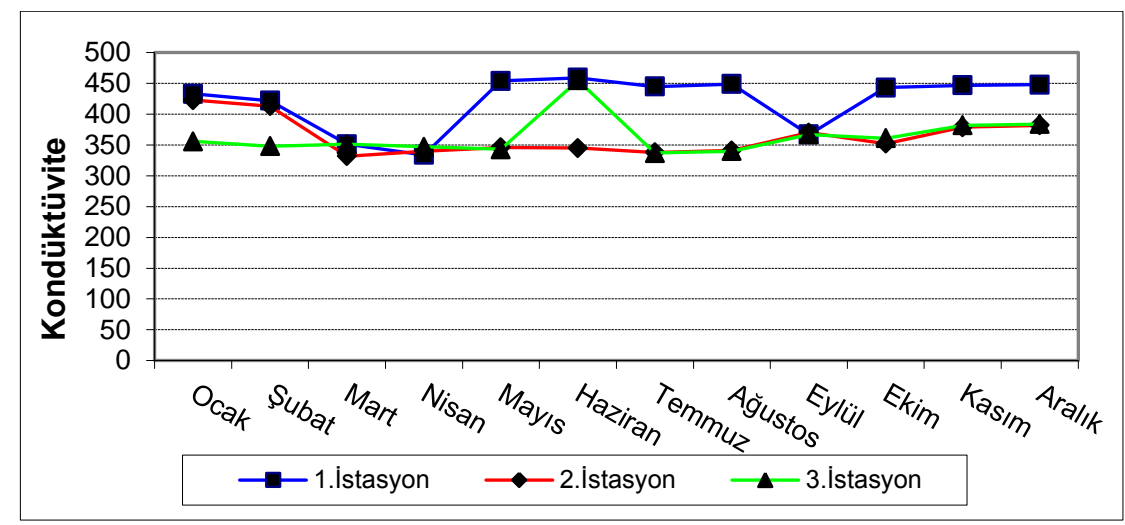

Şekil 5. Kondüktüvite düzeyinin istasyonlara göre aylık değişimi $\left(\mu \mathrm{S} \mathrm{cm}^{-1}\right)$

Kondüktüvite verilerinin istatistiki analizlerinde hem istasyonlar arasında $(\mathrm{p}<0.01)$, hem de mevsimler arasında istatistiki olarak anlamlı fark olduğu $(\mathrm{p}<0.05)$ tespit edilmiştir. Mevsimler x istasyonlar interaksiyonunun istatistiki bakımdan önemli olmadığı belirlenmiştir.

Mutlu, Yanık ve Demir (2013), Karagöl'de yaptıkları çalışmada elektriksel iletkenliğin kış ortalamasını 123,67 $\mu \mathrm{S} \mathrm{cm}{ }^{-1}$, ilkbahar ortalamasını $179 \mu \mathrm{S} \mathrm{cm}^{-1}$, yaz ortalamasını 275,33 $\mu \mathrm{S} \mathrm{cm}^{-1}$ ve

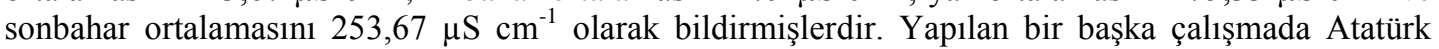
Barajı, Birecik barajı, Karkamış barajı ve Hacı Hıdır barajında tespit edilen minimum ve maksimum elektiriksel iletkenlik değerlerinin sirasıyla $295-4345 \mu \mathrm{S} \mathrm{cm}^{-1}, 314-447 \mu \mathrm{S} \mathrm{cm}^{-1}, 310-479 \mu \mathrm{S} \mathrm{cm}{ }^{-1}$, 254-400 $\mu \mathrm{S} \mathrm{cm}^{-1}$ arasında tespit edildiği rapor edilmiştir (Alp vd. 2010). Hazar Gölü’nde ölçülen elektriksel iletkenlik (EC) değerleri genel ortalama olarak $2260 \mu \mathrm{mhos} / \mathrm{cm}$ 'lik bir değere sahip olup sulama suyu açısından değerlendirildiğinden IV. sınıf su kalite grubuna girdiği ve dolayısıyla sulamaya elverişsiz olduğu bildirilmiştir ( Ünlü vd . 2007). Eğrigöl'de iletkenlik 210-291 $\mu \mathrm{S}_{25^{\circ} \mathrm{C}}$ arasında değişim gösterdiği ve göl içinde iletkenliğin homojen bir dağılıma sahip olduğu bildirilmiştir (Başaran ve Egemen, 2006).

Çalışma sonuçlarımız literatür bilgileri ile örtüşmekle birlikte veriler istasyonlar arasında ve mevsimsel olarak farklılık göstermiştir. Mevsimsel olarak farklılığın bazı iklim parametreleri ve yağışlarla ilişkili olmasından kaynaklı olduğu düşünülmektedir. Buna karşı özellikle farklılığ1 oluşturan 1. İstasyonun baraj gölüne küçük su kaynaklarının karıştığ bölgeye yakınlığ ile izah edilebilecektir. Çünkü elektriksel İletkenlik sudaki toplam çözünmüş madde miktarının bir göstergesi olup, jeolojik yapıya ve yağış miktarına bağlı olarak değişim göstermektedir. (Temponeras ve ark., 2000). Çalışmadan elde edilen verilere göre Germeçtepe baraj gölünde genel elektiriksel iletkenlik ortalaması 382,88 $\mu \mathrm{S} \mathrm{cm}^{-1}$ olarak belirlenmiş ve Yüzey Suları Yönetmeliğine göre I. Kalite su sınıfına sahip olduğu belirlenmiştir. 
Sularda bulunan başlıca azotlu bileşikler, azalan oksidasyon kademesine göre nitrat azotu $\left(\mathrm{NO}_{3}-\mathrm{N}\right),{ }^{\bullet}$ nitrit azotu $\left(\mathrm{NO}_{2}-\mathrm{N}\right)$, amonyak azotu $\left(\mathrm{NH}_{3}-\mathrm{N}\right)$ ve organik azottur (Org-N). Bu azotlu bileşikler ölçülerek, suyun kalitesi hakkında karar verilebilmektedir. Nitrit, azot döngüsünün ara ürünüdür, ortamda birikmez, hemen nitrata dönüşür. Nitrit de nitrat gibi plankton gelişimine katkıda bulunurlar (Taş, 2011). Nisbet ve Verneaux (1970) sudaki nitrit miktarının 1 mg/L'yi geçmesi halinde kirlenmenin başlamış olduğunu ileri sürmektedir.

Çalışma sonuçlarımıza göre Germeçtepe barajında Nitrit düzeyi en düşük 0 , en yüksek ise $0,008 \mathrm{mg} \mathrm{l}^{-1}$ olarak tespit edilmiştir. İstasyonlardan elde edilen aylık Nitrit değişimleri Şekil 6'da verilmiştir.

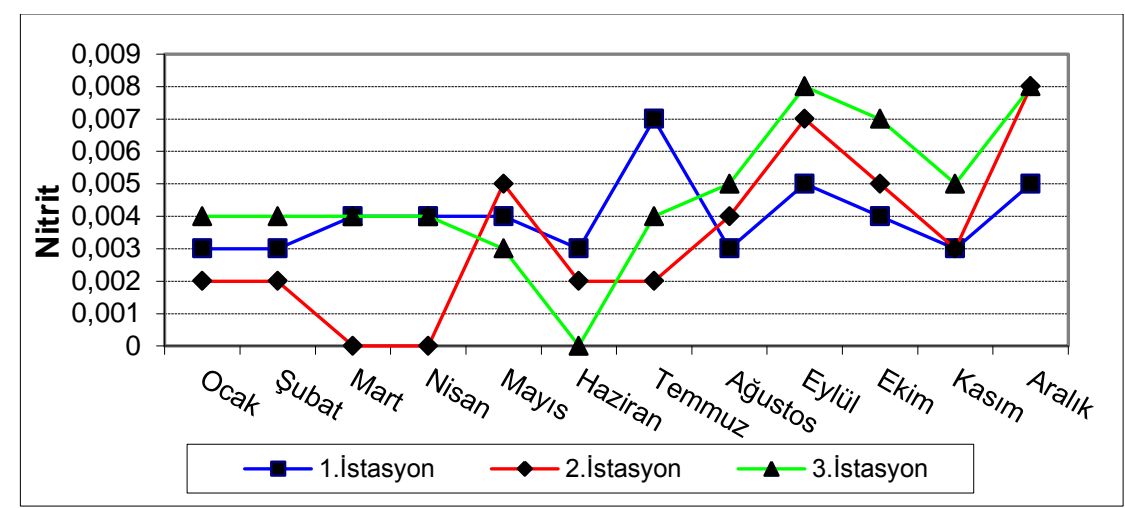

Şekil 6. Nitrit $\left(\mathrm{NO}_{2}-\mathrm{N}\right)$ düzeyinin istasyonlara göre aylık değişimi $\left(\mathrm{mg} \mathrm{l}^{-1}\right)$

Nitrit verilerinin istatistiki analizlerinde hem istasyonlar arasında hem de mevsimler arasında istatistiki olarak anlamlı fark olmadığı $(\mathrm{p}>0.05)$ tespit edilmiştir. Benzer durum Mevsimler $\mathrm{x}$ istasyonlar interaksiyonunda da ortaya çıkmış ve istatistiki bakımdan önemli bir farkın olmadı̆̆ belirlenmiştir.

Taş (2011), Gaga gölünde yaptığı çalışmada araştırma alanında nitrit miktarını ortalama $0,03 \mathrm{mg} \mathrm{1^{-1 }}$ olarak rapor etmiştir. Benzer sonuçlar Ulugöl'de de kaydedilmiş ve $0.014 \mathrm{mg} \mathrm{l}^{-1} \mathrm{NO}_{2}-\mathrm{N}$ kayıtlara geçmiştir. (Taş ve ark., 2010). Karagöl'de mevsimsel nitrit seviyeleri ortalaması; kış 0,001 mg/L, ilkbahar $0,002 \mathrm{mg} / \mathrm{L}$, yaz $0,005 \mathrm{mg} / \mathrm{L}$ ve sonbahar $0,004 \mathrm{mg} / \mathrm{L}$ olarak rapor edilmiştir (Mutlu vd. 2013). Diğer bazı çalışmalarda Yenişehir gölünde ortalama 0,032 mg/L (Tepe, 2009), Eğrigöl'de 04,9 mg/L arasında (Kaymakçı ve Egemen, 2006), Damsa baraj gölünde ise en düşük 0,02 mg/L, en yüksek ise $0,08 \mathrm{mg} / \mathrm{L}$ olarak rapor edilmiştir (Mert vd . 2010).

Germeçtepe barajında yürütmüş olduğumuz çalışmadan elde edilen nitrat verileri referans kaynaklarda yapılan çalışmaların ekseriyetiyle uyuşmaktadır. Hatta veriler bütün istasyonlarda bütün aylarda diğer göllerde ölçülen değerlerin oldukça altında tespit edilmiştir. Bazı ay ve istasyonlarda zaman zaman artış ve azalışlar görülmüşse de genel anlamda nitrit verileri stabil düzeyde seyretmiştir. Çalışma sonucunda $0,0041 \mathrm{mg} \mathrm{l}^{-1}$ genel ortalama elde edilmiştir ki bu ortalama nitrit düzeyi Yüzey Suları yönetmeliğinde belirten sınıflandırmada göl kalitemizin nitrit açısında II. Olduğu sonucunu doğurmaktadır. Öte yandan çizelgede Dünya Sağlık Örgütü, Avrupa Birliği ve ABD Çevre Koruma Ajansının bildirdiği nitrit limitlerinin oldukça altındadır.

Azot ve azot içeren maddeler su kalitesinin belirlenmesinde önemli bir yere sahiptir. Su kaynakları bünyesinde inorganik ve organik kökene sahip azot bileşikleri mevcuttur. Sudaki toplam nitrat ve nitrit iyonu oksitlenmiş azotu gösterir Nitrat bileşiği azotun en büyük yükseltgenme basamağına sahiptir. Su kaynakları içerisinde normal olarak eser miktarda bulunabilmektedir. Nitrat miktarının sularda belirli bir seviyenin üzerine çıkması su kaynağının amonyum ve organik azot barındıran kaynaklarla kirlendiğini veya nitrat içeriğine sahip bir karışım olduğunu göstermektedir. Nitrat ve nitrit miktarı her ne kadar belirli bir dozaja kadar su kaynaklarında istense de bu sınırların üzerinde su canlıları açısından tehlikeli olabilmektedirler (Uslu ve Türkman, 1987; Egemen ve Sunlu, 1997).

Germçtepe barajından üç istasyondan on iki ay boyunca elde edilen nitrat miktarları Şekil 7'de verilmiştir. 


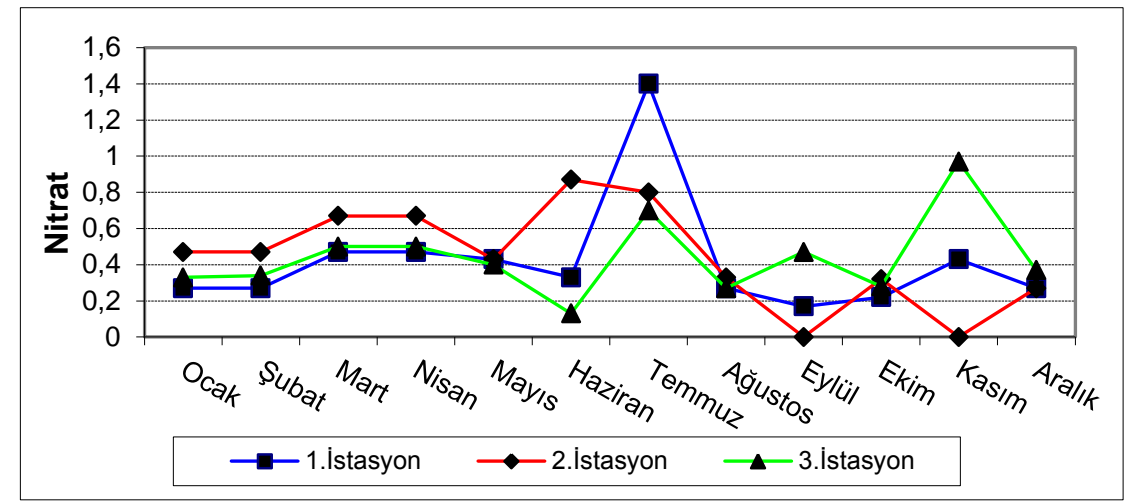

Şekil 7. Nitrat $\left(\mathrm{NO}_{3}-\mathrm{N}\right)$ düzeyinin istasyonlara göre aylık değişimi $\left(\mathrm{mg} \mathrm{l}^{-1}\right)$

Nitrat verilerinin istatistiki analizlerinde hem istasyonlar arasında hem de mevsimler arasında anlamlı fark olmadığ ${ }_{1}(\mathrm{p}>0.05)$ tespit edilmiştir. Benzer durum Mevsimler $\mathrm{x}$ istasyonlar interaksiyonunda da ortaya çıkmış ve istatistiki bakımdan önemli bir farklılık izlenmemiştir.

Şengörür ve Demirel, (2002), Akgöl'de yaptıkları çalışmada nitrat değerini 4,99mg/l olarak rapor ederken belirlenen miktarın standart değerlerini aştığını belirtmişlerdir. Aynı zamanda nitrat düzeyinin değişiminde zaman ve derinliğin etkili olduğunu bildirmişilerdir. Ulubat gölünün su kalitesi üzerine yapılan bir çalışmada nitrat miktarı yaz aylarında $0,685 \mathrm{mg} / \mathrm{l}$, İlkbahar aylarında $0,00 \mathrm{mg} / \mathrm{l}, \mathrm{k} 1$ Ş aylarında $0,116 \mathrm{mg} / 1$ ve sonbaharda $0,00 \mathrm{mg} / 1$ olarak ölçüldüğü rapor edilmiştir (İleri vd . 2014). Özdemir, Yılmaz ve Yorulmaz, (2007), Dalaman çayı üzerinde kurulan hidroelektirik santrali barajında yaptıkları çalışmada nitrat değerlerinin $0,12-2,80 \mathrm{mg}$ L-1 arasında değișiklik gösterdiğini bildirmişleridir. Gaga Gölü’nde ortalama nitrat miktarı $0,93 \mathrm{mg} / \mathrm{L} \mathrm{NO}_{3}-\mathrm{N}$ olarak bildirilirken göl suyunun nitrat bakımından I. Kalite olduğu belirtilmiştir (Taş, 2011). Bir başka çalışmada ise Damsa barajındaki nitrat miktarı nitrat 1,4-6,4 mg/L arasında değişim göstermiştir (Mert vd . 2010).

Germeçtepe barajından elde edilen nitrat düzeylerimiz en düşük $0,00 \mathrm{mg}^{-1}$, en yüksek ise $0,87 \mathrm{mg}^{-1}$ olarak tespit edilmiştir. Genel ortalama $0,42 \mathrm{mg} \mathrm{l}^{-1}$ olarak kayıtlara geçmiştir ki bu literatürde belirtilen diğer çalışmalarla uyum göstermektedir. Nitekim Nitrat, oksijence zengin sularda çok yaygın olup, algal büyümeyi sınırlayabilen veya arttırabilen önemli bir mineraldir. Yüzey sularında nitrat miktarı genellikle düşüktür (Taş, 2011). Baraj gölünün sı̆̆ bir göl olması ve ölçümlerin yüzeyden yapılması elde edilen sonuçları destekler niteliktedir. Verilerin nitrit verileri ile uyum göstermesi de örneklemelerin ve göl suyunun stabilitesi hakkında fikir vermektedir. Ayrıca elde edilen nitrat bulguları standartlar ile karşılaştırıldığında Yüzey suları yönetmeliğine göre belirtilen limitlerden oldukça düşük olduğu ve I. Kalitede olduğu belirlenmiştir. Öte yandan çizelgede listelenen Dünya Sağlık Örgütü, Avrupa Birliği ve ABD Çevre Koruma Ajansının bildirdiği nitrat limitlerinin oldukça altındadir.

Fosfat su kaynaklarında kondanse fosfatlar, ortofosfatlar veya organik bağlı fosfatlar olmak üzere farklı formlarda bulunabilirler. Fosfat su içerisinden ki üretim ve verimliliği direk etkileyen bir parametredir. Bu bileşiklerin sulara karşımı çeşitli yollarla olabilmektedir. Bir ortofosfat bileşiği olan tarımsal gübreler yağmur suları ile su kaynaklarına taşınabilmektedirler. Yine benzer şekilde temizlik alanlarında kullanılan sularda taşınımla su kaynaklarına karışarak fosfat miktarını etkileyebilmektedirler (Munsuz ve Ünver, 1995). Bu nedenle fosfat su kalitesi tayininde sucul yaşam açısından önemli kriter bir parametredir.

Germeçtepe barajından bir yıllık süreçte üç istasyondan elde edilen fosfat değişimleri Şekil 8'de verilmiştir. 


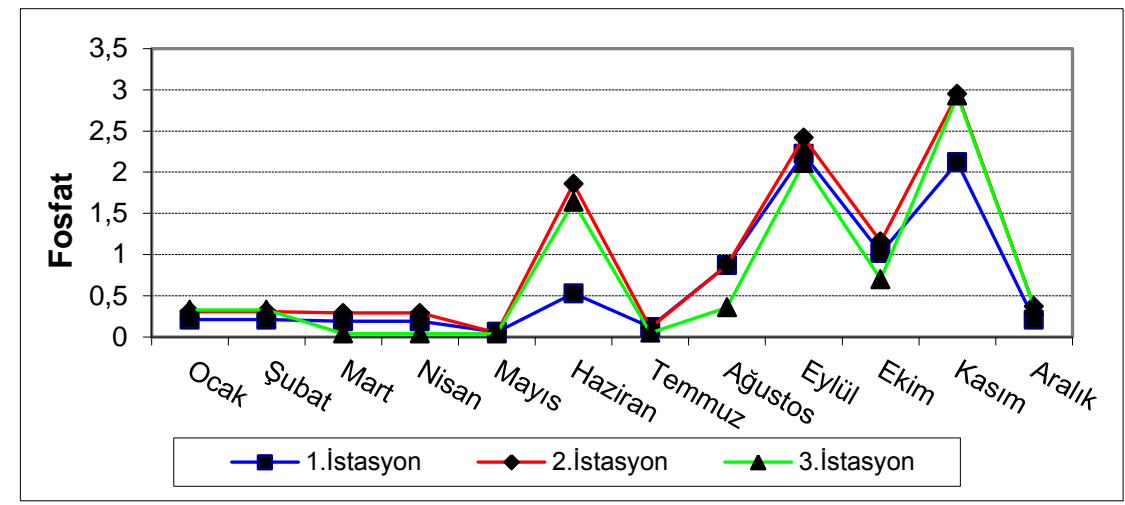

Şekil 8. Fosfat $\left(\mathrm{PO}_{4}\right)$ düzeyinin istasyonlara göre aylık değişimi $\left(\mathrm{mg} \mathrm{l}^{-1}\right)$

Fosfat verilerinin istatistiki analizlerinde istasyonlar arasında farklılık tespit edilmediği fakat mevsimseler arasında istatistiki olarak anlamlı fark olduğu $(\mathrm{p}<0.01)$ belirlenmiștir. Ayrıca mevsimler $\mathrm{x}$ istasyonlar interaksiyonunun istatistiki bakımdan önemli olmadığı belirlenmiştir.

Mutlu, Yanık ve Demir, (2013), Karagöl'de yaptıkları çalışmada fosfat değerlerini kışın 0,14mg/l, İlkbaharda $0,36 \mathrm{mg} / 1$, yazın $0,12 \mathrm{mg} / \mathrm{l}$ ve sonbaharda $0,24 \mathrm{mg} / 1$ olduğunu bildirmiş ve kış ile yaz mevsimlerinde düşük, geçiş mevsimlerinde ise yükselmenin olduğunu rapor etmiştir. Ulubat gölündeki çalışmada fosfat verileri $0,009-0,426 \mathrm{mg} / 1$ arasında değişiklik göstermiştir (İleri vd. 2014). Ulugöl'de ortalama fosfor miktarı $0,010 \mathrm{mg} / \mathrm{L}$ kaydedilmiştir (Taş ve ark., 2010). Gaga gölünde ise fosfor miktar1 0,02 mg/L olarak rapor edilmiştir (Taş, 2011).

Germeçtepe baraj gölünde fosfat miktarı mevsimler arasında farklılık göstermekle birlikte istasyonlar arasında farklılık izlenmemiştir. Daha yüksek fosfor düzeyleri, Kış ve İlkbahar mevsimlerine, özellikle Haziran, Temmuz, Ağustos, Eylül, Ekim, Kasım ve Aralık aylarına kıyasla, İlkbaharın sonunda ve yaz ve Sonbahar mevsimlerinde gözlemlenmiştir. Bununla birlikte, daha düşük düzeyler Aralık, Ocak, Şubat, Mart, Nisan ve Mayıs aylarında gözlemlenmiştir. Sonuçlar ayrıca, daha yüksek fosfor düzeyinin I. İstasyonda (Gölün Başında) gözlemlendiğini ve bunu gölün orta kısmının takip ettiğini ve ayrıca daha düşük fosfor düzeyinin gölün bitiş kısmında gözlemlendiğini netleştirmiş̧tir. Sonuçlarımız, fosfat konsantrasyonunun ilkbaharda ve sonbaharda artış gösterdiğini bildiren Dirican, 2015 ve Mutlu vd. 2013’ün sonuçları ile uyumludur.

Gölde fosfat miktarı 0,04-3,53 $\mathrm{mg} \mathrm{l}^{-1}$ arasında değişim göstermiştir. Genel fosfat ortalaması $0,86 \mathrm{mg}^{-1}$ olarak karşımıza çıkmaktadır. Veriler genel literatürle uyum göstermektedir. Fosfor su ortamında meydana gelen ötrofikasyonun da en temel elementidir (Harper, 1992). Çoğu göllerde ortalama toplam fosfor içeriğinin 0,010 ile 0,030 arasında değiştiği bildirilmiştir (Tanyolaç, 2004). Nisbet ve Verneaux (1970) fosfat içeriğinin $0,15-0,30 \mathrm{mg} / \mathrm{L}$ olan sularda prodüktivitenin yüksek olduğunu ancak bu değerin $0,30 \mathrm{mg} / \mathrm{L}$ 'yi aşması halinde suyun kirlenmiş sayılacağını belirtmektedir. Thoman ve Mueller (1987)'e göre toplam fosfor $10 \mu \mathrm{g} / \mathrm{L}$ 'den küçük ise göl oligotrofik, $10-20 \mu \mathrm{g} / \mathrm{L}$ ise mezotrofik, $20 \mu \mathrm{g} / \mathrm{L}$ 'den büyük ise ötrofiktir. Bu sonuca göre Germeçtepe baraj gölü mezotrofik özellik göstermektedir. Fosfat miktarının yaz aylarında fazla oluşu su miktarının bu mevsimde oldukça düşmesi ile yetiştiricilik faaliyetleri ve suya deşarj olan organik madde miktarının bu mevsimlerde fazla oluşu ile izah edilebilmektedir. Ayrıca göl suyunun fosfat değerlerine göre Yüzey Suları yönetmeliğinde belirtilen limitlerin üzerinde olup IV. Sınıf su kalitesinde değerlendirilmiştir. Amonyum iyonu suda yaşayan organizmalar için önemli ölçüde toksik değildir. Ancak yüksek pH ve sıcaklığa bağlı olarak amonyum amonyağa dönüşerek su ortamı içindeki balık yaşamı ve diğer canlılar için toksik hale gelebilmektedir (Ünlü ve ark., 2008). Temiz ve bol oksijenli sularda amonyum bileşikleri çok düşük düzeylerde bulunmaktadır. Sucul canlıların atık maddesi olup tekrar organizmalar tarafindan absorblanır (Cirik ve Cirik, 1999). Amonyum iyonları birçok alg ve yüksek bitkiler tarafından doğrudan alınabilir. Amonyum, alg büyümesini hızlandırmasının yanında suda oksijen tüketimini artırması ile sucul ortamı etkilemektedir (Haralambous ve ark., 1992). Uzun süredir bilindiği gibi, amonyum bileşikleri belli şartlar altında balıklar için zehir etkisi gösterir. $\mathrm{pH}$ nötr noktasına ne kadar yaklaşırsa amonyak oranı o derece azalır, amonyum oranı da o derece artar. $\mathrm{pH}$ alkali yönde ne kadar artarsa amonyağın zehir etkisi de o derece fazlalaşır (Taş, 2011). Bu nedenle amonyum sularda önemli bir kirlilik göstergesi olabilmektedir.

Germeçtepe baraj gölünde on iki ay boyunca elde edilen amonyum değerleri Şekil 9'da verilmiştir. 


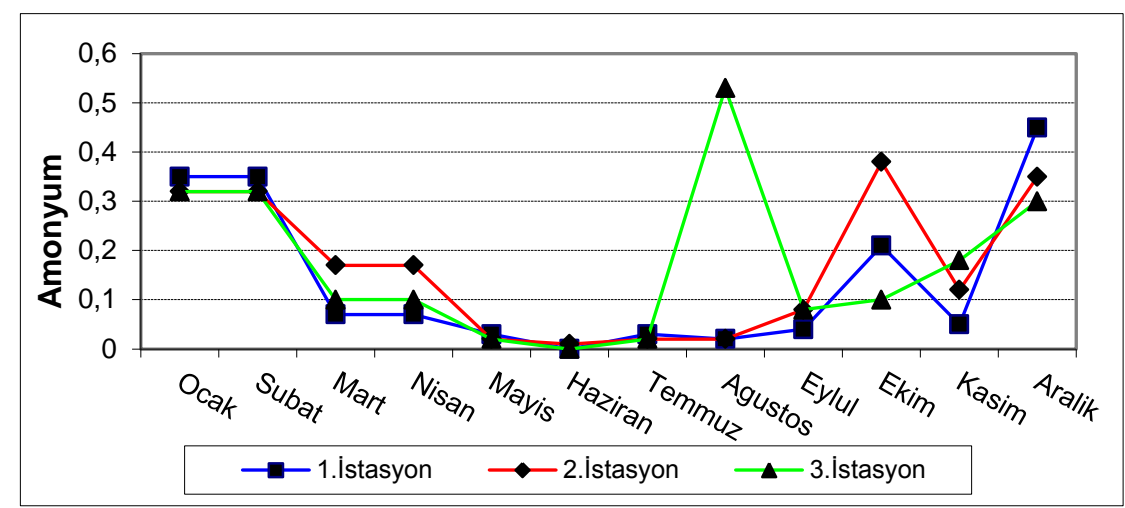

Şekil 9. Amonyum düzeyinin istasyonlara göre aylık değişimi $\left(\mathrm{mg} \mathrm{l}^{-1}\right)$

Amonyum verilerinin istatistiki analizlerinde istasyonlar arasında farklılık tespit edilmediği fakat mevsimseler arasında istatistiki olarak anlamlı fark olduğu $(\mathrm{p}<0.01)$ belirlenmiştir. Ayrıca mevsimler $\mathrm{x}$ istasyonlar interaksiyonunun istatistiki bakımdan önemli olmadığı belirlenmiştir.

Ünlü, Çoban ve Tunç (2008), Hazar gölünün su kalitesi üzerine yaptıkları çalışmada amonyum düzeyini en yüksek değer olarak $0,13 \mathrm{mg} / \mathrm{L}$, en düşük değer olarak ise $0,09 \mathrm{mg} / \mathrm{L}$ olarak tespit etmişlerdir. Güneydoğu Anadolu bölgesinde bulunan bazı barajlarda yapılan bir başka çalışmada Atatürk Barajında 0,14-0,32 mg/L arasında, Birecik barajında 0,20-0,30 mg/L arasında, Karkamış barajında 0,06-0,31 mg/L arasında ve Hacı Hıdır barajında 0,16-0,51 $\mathrm{mg} / \mathrm{L}$ arasında olduğu bildirilmiştir (Alp vd. 2010). Mutlu, Yanık ve Demir (2013), Karagölde yaptıkları su kalitesi çalışmasında amonyum değerini mevsimlere göre $0,01-0,51 \mathrm{mg} / \mathrm{L}$ arasında değiştiğini bildirmiştir. Damsa Barajında yapılan bir başka çalışmada göl suyunun amonyum iyonu konsantrasyonu en düşük değerin kış aylarında $1 \mathrm{mg} / \mathrm{L}$, en yüksek değerin ise Mart ayında 1,8 mg/L olduğu saptandığı rapor edilmiştir (Mert vd . 2010).

Çalışmamızda Germeçtepe barajından elde edilen amonyum verilerine bakıldığında 0,0-0,53mg $1^{-1}$ arasında değişiklik göstermiş ve referans çalışmalarla uyum göstermiştir. Ortalama amonyum düzeyi $0,17 \mathrm{mg} \mathrm{l}^{-1}$ olarak tespit edilen gölde amonyum düzeyi kış ve sonbaharda yaz ve ilkbahara nazaran daha yüksek seyretmiştir ki bu sonuç Tepe, (2009) tarafından Yenişehir gölünde yapılan çalışma sonuçları ile benzerlik göstermektedir. Nihai sonuç itibari ile germeçtepe barajındaki amonyum düzeyi ülkemizde uygulanan Yüzey suları yönetmeliğine göre I. Kalite su sınıfında iken Dünya Sağlık Örgütü (2008) ve Avrupa Birliği (1998) limitlerinin üzerinde seyretmiştir.

Kimyasal oksijen ihtiyacı (KOİ) sudaki yükseltgenebilir maddelerin kimyasal yolla oksitlenmeleri için gerekli oksijen miktarıdır. Evsel ve endüstriyel atıksuların (özellikle endüstriyel) kirlilik derecesini belirlemede kullanılan en önemli parametrelerden biri kimyasal oksijen ihtiyacıdır. Bu nedenle KOİ su kirliliği saptama çalışmalarında en çok kullanılan kollektif bir parametredir.

Germeçtepe baraj gölünde on iki ay boyunca elde edilen Kimyasal Oksijen İhtiyacı (KOİ) değerleri Şekil 10’da verilmiştir.

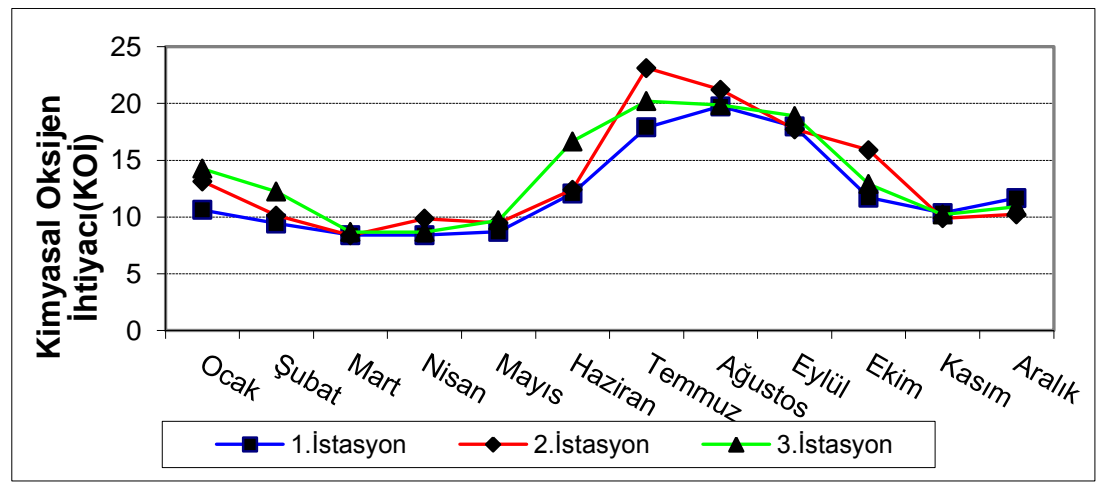

Şekil 10. KOİ düzeyinin istasyonlara göre aylık değişimi $\left(\mathrm{mg}^{-1}\right)$ 
KOİ verilerinin istatistiki analizlerinde istasyonlar arasında farklılık tespit edilmediği fakat mevsimseler arasında istatistiki olarak anlamlı fark olduğu $(\mathrm{p}<0.01)$ belirlenmiştir. Ayrıca mevsimler $\mathrm{x}$ istasyonlar interaksiyonunun istatistiki bakımdan önemli olmadığı belirlenmiştir.

Tepe, Ateş, Mutlu ve Töre (2006), Karagöl'de yaptıkları çalışmada KOİ değerini en düşük 19mg/L, en yüksek ise $50 \mathrm{mg} / \mathrm{L}$ olarak bildirmişleridir. Ulubat gölünün su kalitesinin tespitine yönelik bir başka çalışmada KOİ düzeyi yazın 49,33mg/L, ilkbaharda $56 \mathrm{mg} / \mathrm{L}$, kışın 37,33mg/L ve sonbaharda $53,13 \mathrm{mg} / \mathrm{L}$ olarak tespit edilmiştir (İleri vd. 2014). Yine Ulubat gölünde yapılan bir başka çalışmada yıllık KOİ ortalaması 35,74mg/L olarak bildirilmiştir (Elmacı vd.2010). Diğer bir takım çalışmalarda KOİ miktarı Görentaş göletinde 16,32 ve 20,23mg/L olarak (Tepe vd. 2004), Hafik Karagöl'de 7,8042,19mg/L arasında (Mutlu vd. 2013), Reyhanlı göletinde 18-41mg/L arasında (Tepe, 2009) olduğu rapor edilmiştir.

Germeçtepe barajından elde ettiğimiz KOİ değerleri 8,41-23,13mg $\mathrm{l}^{-1}$ arasında değişim göstermiştir. Ortalama KOİ değeri $13,21 \mathrm{mg}^{-1}$ olarak belirlenmiştir. İstasyonlar arasında değişim önemsiz düzeyde iken mevsimler arasında farklılık ortaya çıkmıştır. Yaz ayları ile birlikte bir artış seyrine giren kimyasal oksijen ihtiyacı diğer aylarda stabil bir Şekil izlemiştir. KOI değeri sularda organik kirlenmeyi gösteren önemli bir parametredir. İlkbahar ve yaz aylarında mikrobiyal aktivitenin artması sebebiyle organik maddelerin bozunma hızları artmakta dolayısıyla KOI değeri de artmaktadır (İleri vd. 2014). Yaz aylarında KOİ düzeylerinin eylül ayına kadar yüksek seyretmesi bu durumun bir getirisi olarak karşımıza çıkmaktadır. Ayrıca bu aylar barajda su seviyesinin en düşük olduğu dönemlere tekabül etmektedir. Bu da sudaki mikrobiyal aktivitenin artmasında önemli bir etken olarak kabul edilebilmektedir. KOİ değerlerimiz ulusal standartlarla karşılaştırıldığında I. Kalite su sınıfına dahil olmaktadır (YSY, 2012)

Biyolojik oksijen ihtiyacı organik maddelerin aerobik şartlarda bozunarak kararlı hale gelmeleri esnasında, bu ortamdaki bakteriler için gerekli olan oksijen miktarı anlamına gelmektedir. Bu nedenle Biyolojik oksijen ihtiyacı (BOI) parametresi, alıcı sular üzerindeki organik kirlilik etkisinin genel bir ölçümü olarak kabul edilen önemli bir parametredir.

Geremçtepe barajından on iki ay boyunca üç istasyondan ölçülen biyolojik oksijen ihtiyacı (BOİ) sonuçları Şekil 11'de verilmiştir.

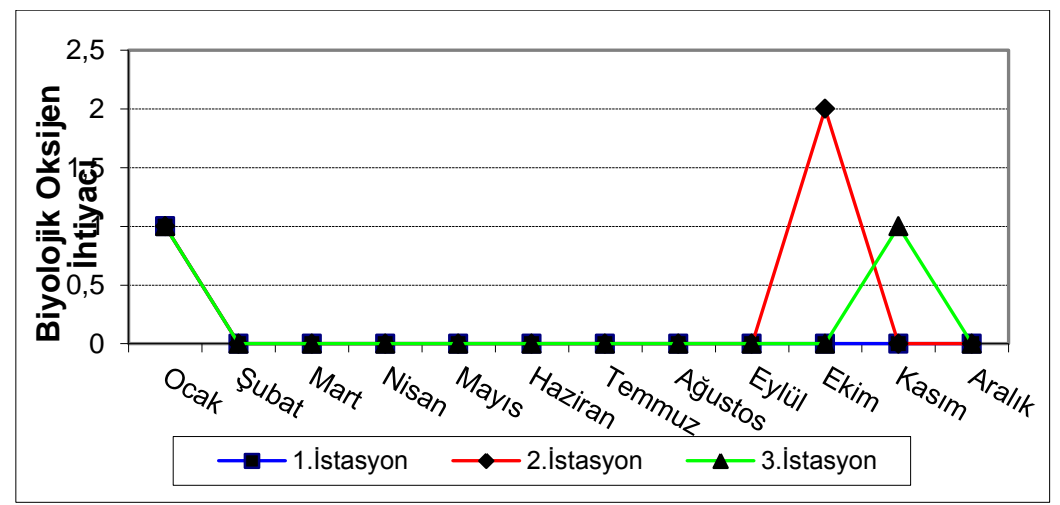

Şekil 11. BOİ düzeyinin istasyonlara göre aylık değişimi $\left(\mathrm{mg} \mathrm{l}^{-1}\right)$

BOİ verilerinin istatistiki analizlerinde hem istasyonlar arasında hem de mevsimler arasında anlamlı fark olmadığ ${ }^{\prime}(\mathrm{p}>0.05)$ tespit edilmiştir. Benzer durum Mevsimler x istasyonlar interaksiyonunda da ortaya çıkmış ve istatistiki bakımdan önemli bir farklılık izlenmemiştir.

Elmacı, Topaç, Teksoy, Özengin ve Başkaya (2010), Ulubat gölünde yaptıkları çalışmda BOİ düzeyini ortalama $21,26 \mathrm{mg} / \mathrm{L}$ olarak belirtmiş ve bu düzeyi yüksek olarak nitelendirmiş̧lerdir. Hazar gölünün su kalitesinin belirlenmesine yönelik olarak yapılan bir başka çalışmada BOİ miktarı 8,9mg/L olarak bildirilmiştir (Ünlü vd., 2008). Atatürk Barajında, Birecik Barajında, Karkamış Barajında ve Hacı Hıdır Barajında su kalitesin eyönelik yapılan ölçümlerde BOİ miktarları aralıkları sırası ile 12,4mg/L, 0,6-1,8mg/L, 1,1-2,7mg/L ve 2,3-6,8mg/L arasında değiştikleri rapor edilmiştir (Alp vd., 2010). 
Çalışma sonucunda elde ettiğimiz BOİ ölçüm sonuçlarına göre Germeçtepe Barajında biyolojik oksijen ihtiyacı düzeyi $0-2 \mathrm{mg} \mathrm{l}^{-1}$ arasında değişim göstermiştir. Genel ortalaması $0,17 \mathrm{mg}^{-1}$ olarak belirlenen BOİ miktarı bakımından göl sularında hiçbir kirlilik emarseni rastlanmamıştır. Elde ettiğimiz değerler litere edilen referans verilerin oldukça altındadır. $\mathrm{Bu}$ durum göle kirlilik oluşturabilecek düzeyde herhangi bir organik kirlilik yükünün karışmadığını göstermektedir. Öte yandan çalışmanın yapıldığı yılda yağışın bol olduğu gerçeği de elde edilen düşük BOİ düzeyini desteklemektedir. Elde edilen ortalama BOİ düzeyi ülkemiz standartları bakımından incelendiğinde Germeçtepe barajı BOİ bakımından I. Kalite sular sınıfındadır.

\section{SONUÇ VE ÖNERILER}

$\mathrm{Su}$ kalitesinin değerlendirilmesi çevre yönetimi ve karar vermede önemli bir rol oynar. $\mathrm{Su}$ kaynaklarının korunması ve akılcı kullanımı için bilimsel bir temel oluşturmaktadır.

$\mathrm{Bu}$ çalışmada Germeçtepe baraj gölünden bir yıl boyunca belirlenen üç istasyondan alınan su numuneleri bazı fiziko-kimyasal parametreler bakımından incelenmiştir. Baraj gölünün su kalitesi 2012 yılında resmi gazetede yayınlanan Yüzey Suları Yönetmeliğine göre sıcaklık, pH, oksijen, kondüktüvite, nitrat, amonyum, KOİ ve BOİ parametreleri bakımından I. Sınıf, Nitrit bakımından II. Sınıf ve fosfat bakımından IV. Sınıf su kalitesi gurubuna dahil olmaktadır. Baraj gölünün genel su kalitesi değerlendirildiğinde istasyonlar arasında ekseriyetle fark olmayışı gölün küçük bir göl olduğundan istasyonlar arasında fazla mesafe olmayışına ve gölü besleyen çok kuvvetli bir kaynağının olmayışına bağlanmıştır. Mevsimsel farklılıkların genel anlamda ortaya çıkışı göl hacminin az oluşundan mütevellit mevsimsel parametre değişimlerinden daha hassas etkilenmesine bağlanmıștır. Fakat bütün bunlara rağmen gölün genel su kalitesine bakıldığında çok yoğun bir kirlilik baskısı altında olmadığı hatta aksine önemli düzeyde bakir kalabildiği görülmüsstür. Bu bakirliğinin en büyük sebeplerinden birisi gölün neredeyse kapalıya yakın bir yapıda olduğundan beseleyen zayıf su kaynağı çok fazla kirlilik unsuru taşımamaktadır. Öte yandan baraj gölünün fazla yakınında yerleşim yeri bulunmadığı gibi tarım arazisi de bulunmamaktadır. Ayrıca yol durumundan dolayı diğer kirlilik unsurlarına da kapalı sayılmaktadır. Göl suyu bu hali ile içinde barındırdığı biyolojik yaşam bakımından elverişli bir ortam olarak değerlendirilmiştir.

\section{TEŞEKKÜR}

Bu çalışma Kastamonu Üniversitesi Fen Bilimleri Enstitüsü'nde yürütülen Enas A. Hamad ATEA'nın yüksek lisans tezinin bir bölümüdür.

\section{KAYNAKLAR}

Alp, M. T. Mehmet A.T. Sen, B. and Ozbay. O. (2010): Water Quality of Surface Waters in Lower Euphrates Basin (Southeastern Anatolia, Turkey). Journal of Animal and Veterinary Advances, 9 (18), 2412 2421.

Bayram, A. and Kenanoğlu, M. (2016). Variation of total suspended solids versus turbidity and Secchi disk depth in the Borçka Dam Reservoir, Çoruh River Basin, Turkey. Lake and Reservoir Management, 32 (3), 209-224.

Başaran-Kaymakçı, A. and Egemen, Ö. (2006). Orta Toros Dağlarındaki Eğrigöl'ün su kalitesi parametrelerinin araştırılması. Ankara Üniversitesi Ziraat Fakültesi. Tarım Bilimleri Dergisi, 12 (2), 137-143.

Cirik, S., Cirik, Ş. 1999. Limnoloji. Ege Üniversitesi Su Ürünleri Fakültesi Yayınları, No: 21, Ege Üniversitesi Basımevi, $166 \mathrm{~s}$, İzmir.

Egemen, Ö., Alparslan, M., \& Sunlu, U. (1997). Çanakkale'de (Karacaören ve Kepez) Toplanan Midyelerde (Mytilus galloprovincialis, Lamarck) Bazı Ağır Metal Düzeylerinin Araştırılması, Ege Üniversitesi Su Ür. Der, 14, 1-2.

Elmacı, A., Topaç, F.O., Teksoy, A., Özengin, N. ve Başkaya, H.S. (2010). Uluabat Gölü Fizikokimyasal Özelliklerinin Yönetmelikler Çerçevesinde Değerlendirilmesi. Uludă̆ University Journal of The Faculty of Engineering and Architecture, 15(1), 149-157.

Goksu, M. Z. L., Yuceer, A., Basibuyuk, M. F. C. F., \& Forster, C. F. (2003). Heavy metal adsorption characteristics of a submerged aquatic plant (Myriophyllum spicatum). Process Biochemistry, 39(2), 179-183

Harper, D. 1992. Eutrophication of fresh waters: Principles, problems and restoration. Chapman and Hall, London, UK.

Haralambous, A., Maliou, E., Malamis, M. 1992. The use of zeolite for amonium uptake. Water Science and Technology, 25(1): 139-145

İleri, S.,Karaer, F., Katip, A., Onur, S. and Aksoy, E. (2014b) Assessment of some pollution parameters with geographic information system (GIS) in sediment samples of Lake Uluabat, Turkey. JBES-Journal of Biological and Environmental Sciences (Kabul Edilmiştir). 
Kaymakçı Başaran, A., Egemen, Ö. 2006. Orta Toros Dağlarındaki Eğrigöl'ün Su Kalitesi Parametrelerinin Araştırılması. Tarım Bilimleri Dergisi 12 (2): 137-143.

Mutlu, E., Yanık, T., and Demir, T. (2013). Karagöl (Hafik-Sivas)'ün Su Kalitesinin İncelenmesi. Alınteri Zirai Bilimler Dergisi, 24, 35-45.

Munsuz, N., \& Ünver, İ. (1995). Su kalitesi. Ankara Üniversitesi, Ziraat Fakültesi, Yay, (1389).

Nisbet, M. and Verneaux, J. (1970). Composants chimiques des eaux courantes: discussion et propositions des classes en tant que base d'interprétation des analyses chimiques. Annales de Limnologie, 6 (2), 161-190.

Obal1, D. (1978). Mogan Gölü Fitoplanktonunun Nitesel Nicesel Olarak İncelenmesi. Ankara Üni.. Fen Fak. Sistematik Botanik Kürsüsü.(Doktora Tezi). Ankara.

Özbek, M., \& Sarı, H. M. (2007). Batı Karadeniz Bölgesi'ndeki Bazı Göllerin Hirudinea (Annelida) Faunası. Ege Üniversitesi Su Ürünleri Dergisi, 24(1-2), 83-88.

Özdemir, N., Yılmaz, F. and Yorulmaz, B. (2007). Dalaman Çayı üzerindeki Bereket Hidro-Elektrik Santrali Baraj Gölü Suyunun Bazı Fiziko-Kimyasal Parametrelerinin ve Balık Faunasının Araştırılması. Ekoloji, 16 (62), 30-36.

Rucinski, D. K., Beletsky, D., DePinto, J. V., Schwab, D. J., \& Scavia, D. (2010). A simple 1-dimensional, climate based dissolved oxygen model for the central basin of Lake Erie. Journal of Great Lakes Research, 36(3), 465-476.

Sönmez, A.Y., Hisar, O., Karataş, M., Arslan, G. and Aras, M.S. (2008). Sular Bilgisi. Nobel Yayın Dağıtım A.Ş. Ankara.

Şahin, B. (2016). Küresel Bir Sorun: Su Kitlığı ve Sanal Su Ticareti. Hitit Üniversitesi Sosyal Bilimler Enstitüsü. Yüksek Lisans Tezi.

Şengörür,B.,\&Demirel, A. (2002). Akgöl'de (Gölkent-Sakarya) Ötrofikasyon Ve Su Kaı. Jite Sınıfının Belirlenmesi. Sakarya Üniversitesi Fen Bilimleri Enstitüsü Dergisi, 6(3), 1-8.

Taş B. 2006. Derbent Baraj Gölü (Samsun) Su Kalitesinin İncelenmesi. Ekoloji, 61: 6-15

Taş, B., Candan, A.Y., Can, Ö. ve Topkara, S. (2010). Ulugöl (Ordu)'ün bazı fizikokimyasal özellikleri. Journal of FisheriesSciences.com, 4(3), 254-263.

Taş B. (2011). Gaga Gölü (Ordu, Türkiye) Su Kalitesinin İncelenmesi. Karadeniz Fen Bilimleri Dergisi / The Black Sea Journal of Sciences, 1, 43-61.

Tanyolaç, J. (2004). Limnoloji (Tatlısu Bilimi). Hatiboğlu Yayıncılık, 239 s, Ankara.

Taş, B., ve Çetin, M. (2011). Gökgöl (Ordu-Türkiye)'ün Bazı Fiziko-Kimyasal Özelliklerinin İncelenmesi. Ordu Üniversitesi Bilim ve Teknoloji Dergisi, 1(1), 75-84.

Tepe, Y. (2009). Reyhanlı Yenişehir Gölü (Hatay) su kalitesinin belirlenmesi. Ekoloji, 18,70, 38-46.

Tepe, Y., Ateş, A., Mutlu, E., Töre, Y. (2006). Karagöl'ün (Erzin-Hatay) bazı fizikokimyasal özellikleri. Ege Üniversitesi Journal of Fisheries and Aquatic Science, 23 (1/1), 155-161.

Temponeras M, Kristiansen J, Moustaka Gouni M. 2000. Seasonal Variation in Phytoplankton Composition an Physical Chemical Feactures of the Shallow Lake Doirani, Macedonia, Greece Hydrobiologia, 424:109122

Thomann, R. V. and Mueller, J. A. 1987. Principle of surface water quality modelling and control. Harper and Row Publishers, 644 p, New York.

Ünlü, A., Çoban, F. and Tunç, M. S. (2008). Hazar Gölü su kalitesinin fiziksel ve inorganik kimyasal parametreler açısından incelenmesi. Gazi Üniversitesi Mühendislik Mimarlık Fakültesi Dergisi, 23 (1), 119-127.

Uslu, O., Türkman, A., 1987. Su Kirliliği ve Kontolü. T.C Başbakanlık Çevre Genel Müdürlüğü Yayınları Eğitim Dizisi.

Verep, B., Çelikkale, M. S. and Düzgüneş, E. (2002). Uzungöl'ün bazı limnolojik ve hidroŞekil özellikleri. Ege Üniversitesi Su Ürünleri Dergisi, 19 (1-2), 233-240.

Yüzey Suları Yönetmeliği. (2012). www.rega.gov.tr. 